\title{
O revigorar do sacramento da Penitência em Portugal
}

\author{
Leandro Alves Teodoro*
}

\section{RESUMO}

O objetivo do presente ensaio é analisar como tratados e manuais de confissão, que circularam em Portugal do final do século XIV ao início do XVI, ensinavam os eclesiásticos do reino, sobretudo os confessores, a apregoar a palavra divina. Partindo do pressuposto de que os referidos livros foram decisivos na fixação e manutenção de regras concernentes ao uso dos sacramentos da Igreja, este trabalho busca interrogar em que medida a confissão penitencial passou a servir, nessa época, não só como ferramenta inquiridora, mas também como um dos principais veículos catequéticos. Mais precisamente, com ênfase, pois, sobre tais guias morais, este texto destaca o papel que os curas de almas precisavam desempenhar, em suas paróquias, para transmitir aos fiéis leigos as advertências e os conselhos elaborados por bispos e outros eclesiásticos cultivados desse período.

Palavras-chave: Portugal; confissão penitencial; purgação dos pecados; tratados de confissão; confessores.

\section{ABSTRACT}

The purpose of this essay is to analyze how treaties and manuals of confession, which circulated in Portugal between the fourteenth- and early sixteenth centuries, taught the clergymen of the kingdom, especially the confessors, how to proclaim the word of God. Starting from the role conferred to these books in fixing and enforcing rules concerning the use of the sacraments of the Church, this work tries to probe how penance confession started to be used at that time not only as an inquiring tool, but also as one of the main instruments for catechesis. More precisely, with emphasis, about such moral guidance, the text aims to highlight the role that soul shepherds needed to play in their parishes in order to be able to pass to the lay faithful warnings and pieces of advice prepared by bishops, and other cultivated clergymen in that period.

Keywords: Portugal; penance confession; purge of sins; treaties of confession; confessors.

DOI - http://dx.doi.org/10.1590/2237-101X0173204

Artigo recebido em 8 de março de 2015 e aprovado para publicaçáo em 19 de maio de 2015.

* Doutor em História pela Universidade Estadual Paulista Júlio de Mesquita Filho (UNESP) e professor do Programa de Pós-Graduação em História da mesma universidade, no campus de Franca (SP), Brasil. É também bolsista FAPESP/CAPES (Processo no 2014/13125-9). Projeto Temático financiado pela FAPESP: Escritos sobre os Novos Mundos: Teorias, métodos e constituição de bancos de dados digitais. E-mail: teodoro400@yahoo.com.br. 
O funcionário régio Garcia de Resende destacou-se, nas primeiras décadas do século XVI, pela compilação de diferentes tipos de obras, como o Cancioneiro Geral e a Crónica de D. João II. ${ }^{1}$ Nessa crônica, ao falar das qualidades de D. João II para legar exemplos de virtudes às geraçôes futuras, mostrou-se impressionado com as práticas penitenciais de seu retratado. ${ }^{2}$ Comentou, a esse respeito, que "o seu confessor, o bispo de Viseu, D. Diogo Ortiz", o considerava um pecador, mas também "um singular penitente". ${ }^{3}$ Adiante, acrescentou que, após a morte deste,

[...] o bispo do Tânger e o prior do Crato secretamente estavam a sós, com a casa despejada, pelo fato de outros senhores terem ido a suas pousadas ordenar a partida para Silves. Como ambos eram feitores do rei, aceitos sempre com ele, abriram uma caixa, da qual este monarca sempre trazia consigo a chave, isso porque ouviram dizer e suspeitavam que ele colocara ali peçonha a qual usaram para matar o bispo D. Garcia [...] Abrindo a caixa com esta boa e leal intenção de bons criados, acharam nela um confessionário e umas disciplinas, e um áspero cilício [...] (grifos nossos). ${ }^{4}$

Tal cena instiga-nos a refletir sobre os motivos que levariam D. Joâo II a possuir tanto dois objetos para autoflagelação - um áspero cilício e um chicote de disciplinas — quanto um confessionário, isto é, um breve manual de confissão. Se esses dois instrumentos pedagógicos poderiam ser usados para o monarca açoitar a si mesmo e provar, pelas feridas deixadas em seu corpo, que estava arrependido por seus deslizes, o manual de confissão servia, contudo, como guia elucidativo no qual encontraria comentários sintéticos a respeito dos pecados mortais e dos princípios elementares da confissão penitencial. ${ }^{5}$ Daí se pode inferir que esse pequeno livro foi a única peça descoberta pelos eclesiásticos que ajudaria o referido rei a entender como o sacramento da Penitência era ministrado.

Malgrado o cronista Garcia de Resende tenha mencionado o nome de objetos relacionados com a prática da penitência que supostamente eram utilizados por um monarca, suas impressôes podem nos guiar, de saída, pela análise do papel dos manuais de confissão na

\footnotetext{
${ }^{1}$ SERRÃO, Joaquim. Figuras e caminhos do Renascimento em Portugal. Lisboa: Imprensa Nacional Casa da Moeda, 1994, p. 15-45.

${ }^{2}$ Sobre os contornos morais do fazer cronístico em Portugal nessa época, sugiro: FRANÇA, Susani Silveira Lemos. Os reinos dos cronistas medievais (Século XV). São Paulo: Annablume, 2006, p. 118-142.

${ }^{3}$ RESENDE, Garcia de. Crónica de D. João II e Miscelânea. Ed. Joaquim Serrão. Lisboa: Imprensa Nacional Casa da Moeda, 1973, p. XXIII.

${ }^{4}$ RESENDE, Garcia de. Crónica de D. João II e Miscelânea, p. 287-288.

${ }^{5}$ BRAGANÇA, Joaquim. Liturgia e espiritualidade na Idade Média. Universidade Católica Editora, 2008, p. 579.
} 
formação moral não apenas de governantes ou de grandes figuras nobres, mas também de homens comuns, pois esse tipo de livro era recheado de liçóes morais direcionadas aos cristãos em geral. ${ }^{6}$ Mesmo que poucos — como D. João II — fossem os leigos iniciados na arte da leitura, os fiéis poderiam apreender os ensinamentos contidos nas páginas desses manuais por intermédio dos próprios sacerdotes, que eram imbuídos da tarefa de divulgar conselhos e informaçóes concernentes ao sacramento da Penitência em suas paróquias ou durante os sermóes apregoados em praças públicas. ${ }^{7}$

O próprio Garcia de Resende escreveu, em meados do Quinhentos, uma espécie de manual de confissão, conhecido como Memorial dos pecados, no qual incita homens casados, velhos, mancebos e viúvos a confessarem humildemente seus pecados para o confessor. Segundo ele, cada fiel cristão "deve olhar para o estado em que vive e observar se faz o necessário e o que é obrigatório de se fazer". ${ }^{8}$ A partir de obras como essa e de muitas outras ainda mais detalhadas e volumosas eram definidos, como veremos, os procedimentos a serem adotados para os fiéis cristãos purgarem seus pecados.

Garcia de Resende inicia o referido manual sugerindo que o penitente faça a seguinte oração antes de encontrar com seu confessor: "Senhor, por Tua paixão e infinita misericórdia, queiras abrir meu entendimento, memória e vontade, para que eu, com muita contrição e arrependimento,possa confessar todos meus pecados, fazer verdadeira penitência e saber de outros guardar". ' O esperado por esse letrado era que o penitente, ao mentalizar ou ditar em voz alta essa oração, chegasse à confissão penitencial já sensibilizado pela dor de seus pecados e mais focado no exame de sua vida. Tão focado que deveria, nas palavras de Garcia de Resende, se colocar "de joelhos aos pés do confessor com muito acatamento e com o rosto baixo [...]". ${ }^{10}$ Numa época em que os gestos eram reconhecidos como espelhos da alma, ${ }^{11} \mathrm{o}$ rosto baixo e, principalmente, o corpo prostrado refletiam, na opiniáo de muitos clérigos, uma imagem de dor e contrição, ou melhor, revelavam ao mundo o arrependimento guardado no fundo da consciência.

Garcia de Resende esteve longe, contudo, de angariar a mesma confiabilidade que os eclesiásticos diocesanos gozavam, já que estes eram considerados a autoridade máxima nos bispados e arcebispados em assuntos relacionados com o uso dos sacramentos da Igreja. Por

\footnotetext{
${ }^{6}$ MICHAUD-QUANTIN, Pierre. Les méthodes de la pastorale du XIII ${ }^{\mathrm{e}}$ auXV ${ }^{\mathrm{e}}$ siècle, Miscellanea mediaevalia, v. 7, 1970.

${ }^{7}$ ROUCHE, Michel. Histoire de l'enseignement et de l'éducation. Paris: ÉditionPerrin, 2003, p. 634-635. Cf. SAENGER, Paul. La lectura en los últimos siglos de la Edad Media. In: CHARTIER, Roger; CAVALLO, Guglielmo (Org.). Historia de la lectura. Madri: Taurus, 2011, p. 183.

${ }^{8}$ RESENDE, Garcia de. Breve memorial dos pecados e cousas que pertenecem ha confissam hordenado. Ed. Joaquim Bragança. Lisboa: [s. n.], 1980, p. 24.

${ }_{9}^{9}$ RESENDE, Garcia de. Breve memorial dos pecados e cousas, op. cit., p. 24.

${ }^{10}$ Idem.

${ }^{11}$ SCHMITT, Jean-Claude. La raison des gestes dans l'Occident Médiéval. gestes dans l'Occident Médiéval. Paris: Gallimard, 1990, p. 38-39.
} 
isso, embora esse nobre tivesse compilado um opúsculo em forma de manual de confissão, os tratados elaborados por clérigos cultivados eram os livros mais indicados para auxiliar os confessores no exame da consciência dos fiéis. Clérigos como o já mencionado D. Diogo Ortiz - confessor de D. João II — que, conquanto não nos tenha legado tratados específicos sobre a confissão penitencial ou sobre os pecados mortais, elaborou, todavia, a célebre obra $O$ catecismo pequeno, na qual reservou algumas páginas, sobretudo os últimos capítulos, para advertir os sacerdotes a respeito do modo como deveriam intervir na vida dos cristáos pecadores. Ao contrário, portanto, de Garcia de Resende, que procurou transmitir apenas breves liçôes aos penitentes, D. Diogo Ortiz foi mais além e redigiu algumas prédicas acerca do que julgava ser a eficiência pedagógica e reabilitadora do sacramento da Penitência.

No momento em que D. Diogo Ortiz começa a esquadrinhar os sacramentos da Igreja, esclarece aos seus leitores que "a Penitência é ordenada diretamente contra os pecados mortais e é uma tábua que temos depois de perdida e britada a nave da inocência”. ${ }^{12}$ Acerca das possibilidades de recuperação das almas consideradas pecadoras, S. Tomás de Aquino uma das principais autoridades do pensamento escolástico — , de maneira semelhante a esse bispo, asseverara, na Suma Teológica, que, enquanto o Batismo, a Eucaristia e a Confirmação eram sacramentos necessários para prevenir os cristãos, a Penitência não passava, entretanto, de um recurso utilizado para salvá-los depois de terem cometido algum ato pecaminoso. Em outras palavras, na opinião do Doutor Angélico, se "os três sacramentos precedentes (Batismo, Eucaristia e Confirmação) garantiriam a integridade do navio", a Penitência era a principal esperança num eventual "naufrágio", por conseguir socorrer as almas "afogadas". ${ }^{13}$ Ao comparar a vida a uma viagem por fortes e impetuosos mares, tanto D. Diogo Ortiz quanto Tomás de Aquino concluíram seu raciocínio, afirmando que a confissão penitencial nada mais era do que "a segunda tábua depois do naufrágio". Por meio de uma linguagem metafórica tão cara aos principais teólogos da época, ambos buscaram, nesse sentido, orientar os leitores de seus tratados a reconhecerem o sacramento da Penitência como uma espécie de "escola" de reabilitação de pecadores, a qual poderia, segundo eles, corrigir as máculas de muitos fiéis, na medida em que os redirecionava para uma vida considerada mais virtuosa.

Vista como caminho para atingir a salvação, como base para remissão dos pecados e como prática de exortação das virtudes, a confissão penitencial impôs-se, desse modo, a partir do século XIII, como um sacramento importante e que merecia a atenção dos compiladores eclesiásticos para confeccionarem livros específicos a seu respeito. ${ }^{14}$ Além de obras como $O$ catecismo pequeno, de D. Diogo Ortiz, foi redigido, em Portugal, outro tipo de tratado com regras ainda mais precisas e ordenadas para regular os usos do sacramento da

\footnotetext{
${ }^{12}$ DIOGO ORTIZ. O catecismo pequeno. Ed. de Elsa Maria Branco da Silva. Lisboa: Ediçóes Colibri, 2001, p. 261.

${ }^{13}$ TOMÁS DE AQUINO. Suma teológica. São Paulo: Ediçôes Loyola, 2006, v.IX, quest. 84, art. 7, p. 480-481.

${ }^{14}$ MINOIS, Georges. Le confesseurduroi. Les directeurs de conscience sous la monarchie française. Paris: Fayard, 1988, p. 104-105.
} 
Penitência. Vale adiantar que todo o ensinamento que se encontra neste gênero, chamado de tratado de confissão, foi elaborado para explicar aos homens os prejuízos de cometerem algum pecado e, paralelamente, os benefícios que o reconhecimento dos erros lhes traria. São livros destinados, assim, a mostrar aos fiéis a existência, no mundo, de sinais da presença de Deus que estava apagada de suas vidas, segundo os teólogos dessa época, em razão da mácula de seus deslizes. ${ }^{15}$

Entre os tratados de confissão confeccionados em solo português e conhecidos em língua vernácula, o primeiro que aparece - nos moldes difundidos largamente no meio clerical nesse período - é o Livro das confissóes, de Martín Pérez, compilado no ano de 1399, pelo religioso Roque de Thomar, no mosteiro cisterciense de Alcobaça. Tempos depois, mais precisamente em 1488, surge o Sacramental, do clérigo leonês Clemente Sánchez, e, em 1489, o Tratado de confissáo, de um compilador anônimo e que, apesar do nome, não passava de um simples manual, obras essas que foram impressas na mesma cidade portuguesa de Chaves. A refundição desses tratados foi importante não só para a promoção do ensino religioso, mas também para divulgar, em língua portuguesa, os nomes e os significados de cada sacramento da Igreja. ${ }^{16}$ Como até a primeira metade do Quinhentos os confessores letrados de Portugal não tinham ainda o hábito de elaborar seus próprios tratados de confissão, tornou-se uma atitude corriqueira buscar, na versão portuguesa dos tratados castelhanos de Pérez, de Sánchez, bem como no Tratado de confissäo de origem incerta, as bases consideradas fundamentais para a formação moral dos confessores.

Na passagem do século XIV para o XV, os prelados portugueses passaram a incentivar a compilação de tratados de confissão, na medida em que foram precisando de novos instrumentos pedagógicos para instruir os párocos que não dominavam o latim e que mostravam não conhecer minimamente os dogmas da Igreja. A respeito da formação moral da clerezia ibérica, destaca Sánchez que

[...] muitos sacerdotes, que são curas de almas, náo somente são ignorantes para instruir e ensinar a fé e crença e as outras coisas que pertencem a nossa salvação, mas ainda não sabem o que todo bom cristão deve saber, nem são instruídos, nem ensinados na fé cristã, segundo deveriam, o que é mais perigoso é que muitos não sabem as sagradas escrituras. ${ }^{17}$

Após tecer essas impressões, tal eclesiástico explica que os clérigos com cura de almas

${ }^{15} \mathrm{Cf}$. CHIFFOLEAU, Jacques. Avouerl'inavouable. L'aveu et la procédure inquisitoire à la fin du MoyenAge. In: DULONG, Renaud (Dir.). L'aveu. Histoire, sociologie, philosophie. Paris: Puf, 2001, p. 85-89.

${ }^{16}$ Para entender melhor a obra desses autores de tratados de confissão, sugiro: SOTO RÁBANOS, Jose María. Visión y tratamiento del pecado en los manuales de confesión de la Baja Edad Media hispana, Hispania Sacra, v. LVIII, n. 118, p. 411-447, jul./dec. 2006. MACEDO, José Rivair. Os manuais de confissão luso-castelhanos dos séculos XIII-XV, Revista Aedos, v. 2, n. 2, 2009.

${ }^{17}$ SÁNCHEZ, Clemente. Sacramental. Ed. José Barbosa Machado. Lisboa: Ediçóes Vercial, 2010, p. 32. 
precisavam "ser muito bem instruídos e preparados para iluminar os leigos, pois, se assim não fossem, estes seriam cegos", ${ }^{18}$ Como as obras das principais autoridades do pensamento cristão abordavam temas considerados complexos demais e eram geralmente redigidas em latim - uma língua pouco familiar, na época, a muitos clérigos diocesanos —, os tratados de confissão foram elaborados para proporcionar uma leitura simplificada, mas não menos proveitosa e elucidativa sobre as regras que deveriam gerir o ofício dos confessores. Martín Pérez explica, por exemplo, que elaborou o Livro das confissóes para que os confessores aprendessem, "com pouco estudo, a doutrina da vida para as almas salvar". ${ }^{19}$ Clemente Sánchez usou o mesmo argumento ao confessar os motivos que o levaram a redigir o Sacramental: "eu, Clemente Sánchez de Vercial, bacharel em leis, ainda que pecador e indigno, propus fazer uma breve compilação das coisas que são necessárias aos curas de almas saber [...]". ${ }^{20}$

Entre as liçôes transmitidas aos confessores por esses eclesiásticos letrados, destacam-se, sobretudo, as prédicas a respeito dos usos do termo "penitência". Visando clarear o significado desse vocábulo, esse mesmo Clemente Sánchez assevera que,

[...] segundo S. Ambrósio, penitência é chorar os pecados passados. Já S. Agostinho diz que a penitência é uma vingança que provoca dor e arrependimento por meio da pena e da dor do mal feito. E ainda S. Ambrósio diz que penitência é dor de coraçấo e amargura da alma pelos pecados que cada um cometeu. ${ }^{21}$

Assim como tal teólogo, Martín Pérez explica que "penitência, conforme enunciam os doutores da santa igreja, é verdade e graça com a qual alvorecemos e choramos pelos males que fizemos, com propósito de fazer emenda deles e com vontade de não voltar a praticá-los". ${ }^{22} \mathrm{Na}$ sequência, consegue ser mais enfático ao reunir numa mesma lista os três principais significados desse vocábulo em questão:

1 - Às vezes, dizemos penitência por ser aos pés do sacerdote e por confessar e receber absolvição do clérigo. 2 - Às vezes, chamamos penitência aquela que recebemos do clérigo para fazer a Deus emenda dos nossos pecados. 3 - Chamamos, outrossim, penitência aquela dor que tem a alma de dentro por seus pecados, uma dor demonstrada, às vezes, do lado de fora por lágrimas, gemidos e suspiros. ${ }^{23}$

Ao revisarem certas autoridades cristãs, tanto Sánchez quanto Pérez mostravam-se con-

\footnotetext{
${ }^{18}$ Ibidem, p. 31.

${ }^{19}$ PÉREZ, Martín. Livro das confissóes. Ed. de José Barbosa Machado e Fernando Alberto Torres. Braga: Ediçôes Vercial, 2009, v. I, p. 22.

${ }^{20}$ SÁNCHEZ, Clemente. Sacramental, op. cit., p. 32.

${ }^{21}$ Ibidem, p. 223.

${ }^{22}$ PÉREZ, Martín. Livro das confissóes, op. cit., v. II, p. 63.

${ }^{23}$ Idem.
} 
victos de que a palavra "penitência" poderia ser usada para dar nome não apenas à prescrição sentenciada pelo confessor, mas também ao ritual de purgação dos pecados e a toda demonstração de arrependimento pelo pecado cometido.

Sánchez não deixa de comentar que a palavra "penitência", quando usada para expressar a purgação dos pecados, poderia designar ainda três procedimentos diferentes, pois havia, segundo ele, "a Penitência solene, a pública e a secreta". ${ }^{24}$ Desdobrando melhor seu raciocínio, explica que a Penitência solene possui esse nome "porque se faz com grande solenidade e se deve fazer dessa seguinte maneira: o fiel deve ir na quarta-feira de cinzas, que é o primeiro dia da quaresma, descalço à porta da igreja e, depois, por toda a quaresma, morar em uma cabana". ${ }^{25} \mathrm{O}$ confessor só poderia sentenciá-la, contudo, uma vez para cada fiel, e apenas quando este cometesse algum grave e escandaloso pecado que chegasse a prejudicar, de algum modo, a sua vila ou uma grande quantidade de pessoas. Em voga desde o século X, esta forma de penitência impunha uma série de interditos; por exemplo, depois de recebê-la, o fiel nunca mais poderia se casar nem mesmo usar roupas coloridas. Já a Penitência pública, segundo Sánchez, "se faz em público, mas não com solenidade". ${ }^{26}$ Para ser imposta, o criminoso que cometesse algum pecado considerado hediondo, como homicídio, deveria ser advertido na frente de outras pessoas, durante as solenidades eclesiásticas, e orientado a realizar alguma peregrinaçáo para purgar seu erro. ${ }^{27}$ Cumprindo uma espécie de ostracismo temporário, era forçado a isolar-se de seus familiares para se entregar a uma vida de oraçôes e de comedimentos, isto é, distanciando-se de todas as pessoas de seu convívio, teria mais tempo, segundo os confessores, para refletir sobre suas falhas. Além desse tipo de penitência, Sánchez tratou de dissertar, em vários capítulos do Sacramental, acerca daquela que dizia ser a mais importante: a confissão penitencial. Na verdade, o ponto alto desse tratado de confissão são os conselhos reservados para ensinar aos curas de almas a realizar corretamente essa prática penitencial que era a única - desse conjunto de açôes salutares listadas no referido tratado - reconhecida, na época, como um sacramento da Igreja. Por isso, uma das principais metas de Sánchez e de outros clérigos eruditos dos séculos XIV e XV era inventariar normas e conselhos que pudessem ajudar o confessor a orientar o pecador, de maneira rápida e eficiente, no momento em que este lhe confessasse seus erros.

Pérez e Sánchez buscaram explicar, em seus tratados de confissão, que a relação entre o penitente e o confessor precisava ocorrer num forte jogo de alerta perpétuo, pois exigia daquele que confessava concentração para lembrar exatamente de cada detalhe de seus pecados, e daquele que escutava, diligência para saber prescrever as admoestaçôes adequadas ao ouvir cada pecado descrito ao longo da confissão. ${ }^{28}$ Essa definiçáo do sacramento da Peni-

\footnotetext{
${ }^{24}$ SÁNCHEZ, Clemente. Sacramental, op. cit., p. 218.

${ }^{25}$ Ibidem, p. 219.

${ }^{26}$ Idem.

${ }^{27}$ RAMOS-REGIDOR, José. Teologia do sacramento da penitência. São Paulo: Paulus, 2006, p. 202-203.

${ }^{28}$ MICHAUD-QUANTIN, Pierre. Sommes de casuistique et manuels de confessionau Moyen Âge (XII-XVI
} 
tência como instrumento de amparo espiritual fez fortuna nessa época, ganhando destaque, em muitas outras obras, como no tratado de confissáo Manipulus Curatorum (o manual da cura), de Guido de Monte Roterio, redigido em latim, no ano de 1331, e impresso em Portugal — no ano de 1523, pelo tipógrafo Germano Galharde —, em língua castelhana. Nesse tratado, ao cristão é ensinado que a confissão penitencial não só faz "quitar e perdoar o pecador" como também consegue reconciliá-lo "com Deus e com a Igreja”. A ele também é ensinado que "o estado do pecado é nomeado de trevas", enquanto o momento de reconciliação com o plano superior se chama "graça ou luz". ${ }^{29}$

Ao dissertar, de maneira semelhante a Guido de Monte Roterio, sobre o "estado de trevas", Clemente Sánchez defende que "pecado é vontade de ter ou de seguir o que a justiça veda e defende. $\mathrm{Ou}$, em outras palavras, é cobiçar ou fazer algo de errado contra a lei de Deus. Por isso, faz com que o homem tenha seu verdadeiro ser esfacelado" ${ }^{30}$ Complementando sua análise, esse mesmo clérigo listou as sete maneiras consideradas, na época, indispensáveis para que o cristão conseguisse recuperar o caminho certo e reparar sua existência:

[...] a primeira é no batismo. A segunda é no matrimônio. A terceira é fazer esmola. A quarta é perdoar aqueles que erraram, porque Deus perdoa eles. A quinta quando homem se converte do erro se torna ao caminho de Deus. A sexta é muito grande caridade como foi a de Madalena. A sétima é a penitência e choro de lágrimas, assim quando alguém confessa ao sacerdote como deve. $^{31}$ (Grifos nossos)

Não é por menos, então, que o confessor se tornou uma espécie de "arquiteto" de novas vidas, já que deveria ajudar até o mais desesperado e angustiado pecador a reconstruir sua existência. Essa reconstrução de si por meio da verbalização dos pecados era vista como um exercício terapêutico que só funcionaria se fosse praticado regularmente do início ao fim da vida, pois o cristáo nunca poderia se considerar uma obra acabada, a ponto de querer enfrentar sozinho as suas tribulaçôes. Para Sánchez e Guido de Monte Roterio, até o cristão mais sábio e conhecedor dos mandamentos divinos não conseguiria se desatar das amarras dos pecados sem ajuda de um confessor disposto a orientá-lo. Por isso, qualquer cristão que recusasse o apoio de um clérigo seria qualificado de soberbo e orgulhoso, isto é, aos olhos dos confessores, não passaria de mais um pecador que não conhecia as consequências negativas de seus atos.

siècles). Louvain: Nauwelaerts, 1962, p. 68-71.

${ }^{29}$ GUIDO DE MONTE ROTERIO. Manipulus curatorum. Lisboa: Germano Gallarde, 1523, f. 102.

${ }^{30}$ SÁNCHEZ, Clemente. Sacramental, op. cit., p. 74.

${ }^{31}$ Ibidem, p. 39. 
Antes dos séculos XII e XIII, quando as dioceses ibéricas não haviam criado ainda um sistema catequético mais atuante em todos os âmbitos da sociedade, ${ }^{32}$ os eclesiásticos mostravam-se preocupados, contudo, muito mais com as sentenças a serem prescritas ao penitente do que propriamente com a instrução elementar deste cristão, ou melhor, alegavam que a severidade e a punição seriam as principais estratégias utilizadas pelos confessores para recuperar a alma do pecador. ${ }^{33}$ Náo foram, pois, poucos os clérigos que procuraram confeccionar livros repletos de penas de caráter universal e impessoal para serem sentenciadas na hora da confissão. ${ }^{34}$ Uma dessas obras é o Penitencial — atribuída a Beda, o Venerável, e provavelmente elaborada no início do século VIII - na qual o homem casado que tiver relaçôes pecaminosas com uma mulher comprometida é condenado a ficar "três anos em jejum" e, no primeiro, sem poder se aproximar de sua esposa. ${ }^{35}$ Para os defensores desse modelo jurídico, conhecido como penitência tarifária, o confessor, quando fosse interrogar o cristão adúltero, não precisava avaliar, por exemplo, se este réu mostrava ou não sinais claros de arrependimento, pois, como inquiridor, o seu dever era puni-lo, e não necessariamente ensiná-lo os riscos decorrentes da luxúria. ${ }^{36}$

Tal sistema de punição já havia caído praticamente em desuso entre os séculos XIII e $\mathrm{XIV}$, período em que os clérigos passaram a ser aconselhados a avaliar cada detalhe do crime confesso, bem como o modo pelo qual o cristão externava suas faltas. Clemente Sánchez, por exemplo, ao enfatizar a maneira como o penitente deveria expor seu pecado, sugere ao varão adúltero que se confesse da seguinte forma: "Pequei porque muitas vezes toquei e contratei mulheres com intenção de luxúria e de ter deleitação. E procurei poluição de minha própria vontade $[. .$.$] e beijei muitas mulheres" { }^{37}$ Ao confessar nesses moldes, era esperado do homem uma autoacusaçáo pormenorizada de suas faltas, que deveria ser complementada com choros e expressôes de remorso, tudo isso para convencer o confessor de que queria se redimir de seus pecados. ${ }^{38}$

${ }^{32}$ NIETO SORIA, José Manuel; SANZ SANCHO, Iluminado. La época medieval: Iglesia y cultura. Madridl: Ediciones Istmo, 2002, p. 189-193.

${ }^{33}$ Ao refletir sobre a penitência tarifária, o pesquisador Michel Foucault considera que "a ideia de uma confissão geral de todos os pecados [...], a ideia de que essa revelação poderia ser de uma eficácia qualquer na remissão do pecado estava absolutamente excluída pelo sistema. Se podia haver remissão dos pecados, era unicamente em razão da severidade das penas que o indivíduo se aplicava, ou aceitava se aplicar, adotando o estatuto de penitente”. FOUCAULT, Michel. Os anormais. São Paulo: Martins Fontes, 2002, p. 217.

${ }^{34}$ Sobre os penitenciais que circularam na Península Ibérica durante a Alta Idade Média, sugiro: BEZLER, Francis. Les pénitentiels espagnols. Contribution à l'étude de la civilisation de l'Espagnech rétienne du haut Moyen Âge. Münster: Aschendorff Verlag, 1994. E sobre os tratados de confissão que passaram a ser compilados nesse canto do mundo cristáo, ver: REINHARDT, Klaus; SANTIAGO-OTERO, Horacio. Biblioteca bíblica ibérica medieval. Madri: Consejo Superior de Investigaciones Científicas, 1986.

${ }^{35}$ VOGEL, Cyrille. Le pécheur et la pénitenceau Moyen Âge. Paris: Cerf, 2007, p. 75.

${ }^{36}$ Sobre a confissão tarifada, sugiro: RAMOS-REGIDOR, José. Teologia do sacramento da penitência, p. 193-196.

${ }^{37}$ SÁNCHEZ, Clemente. Sacramental, op. cit., p. 245.

${ }^{38}$ DELUMEAU, Jean. A confissão e o perdão. São Paulo: Companhia das Letras, 1991, p. 47-58. 
Outra mudança entre a passagem do sistema tarifário para a confissão penitencial foi a necessidade de atribuir mais autoridade e autonomia ao próprio confessor no processo de julgamento do pecado. Acerca das sentenças a serem praticadas pelo fiel, esclarece Martín Pérez, numa versão condensada do Livro das confissöes, ${ }^{39}$ que a penitência poderia ser sentenciada de maneira "arbitrária" em determinados casos, isto é, prescrita de acordo com avaliação do próprio confessor, e não segundo as tabelas fixadas pelos penitenciais, em razão de três motivos:

Primeiro, porque os códigos da santa Igreja não determinaram todas as penitências para todos os pecados. São tantas as maneiras que o Diabo acha para fazer os homens pecar que não seria possível estabelecer previamente emendas para todos os pecados. Mas fizeram algumas emendas sobre alguns pecados. E deixaram no árbitro dos confessores que a penitência por aqueles pecados julguem eles [...] A outra razão é porque existem maneiras escondidas de fazer emenda a Deus dos pecados. Convém saber, grande contriçãa, grande fé, grande amor e corregimento da vida [...] Pois, quanto mais emenda o fiel faz dentro de si, menos penitência the deve ser colocada de fora. [...] A terceira razão que fez com que as penitências ficassem no juízo dos confessores é pela fraqueza de alguns pecadores que náo são tão fortes dos corpos para sofrerem a penitência [...]. E porém deixaram no juizo dos confessores que olhem as idade, forças, as condiçôes, as companhias, as moradas, as terras, as qualidades dos pecadores e assim thes ponham aquela penitência que entendam que poderiam bem sofrer. ${ }^{40}$ (grifos nossos).

Ao mirarem a reabilitação dos pecadores, Sánchez e Pérez consideravam que a prática da penitência, isto é, o cumprimento de alguma punição, não causaria efeitos positivos se não fosse antecedida por alguma ação que demonstrasse dor e arrependimento. ${ }^{41}$ Para eles, diferentemente do que defendia Beda, o ato de penitenciar deveria ser, portanto, apenas uma das etapas do longo processo de purgação dos pecados, e não o esteio de todo esse complexo sistema inquiridor.

Nos principais centros de ensino e de debate teológico, a confissão auricular tornou-se, entre os séculos XII e XIII, um assunto incontornável, e seus defensores - como Pedro Abelardo, Hugo de S. Vitor, Pedro Lombardo, Raimundo de Peñafort e Tomás de Aquino - procuravam expor aos mais conservadores e avessos às novas tendências pedagógicas seu ponto de vista acerca da purgação dos pecados mortais, ou melhor, foram esses os primeiros teólogos a lançar luz sobre o papel do reconhecimento da culpa como ferramenta de exame

\footnotetext{
${ }^{39}$ Aqui nos referimos ao códice alcobacense 213, que nada mais é do que uma fatia extraída pelos cistercienses do volumoso Livro das confissóes. José Barbosa Machado publicou esse pedaço da obra de Pérez junto com o referido tratado de confissão.

${ }^{40}$ PÉREZ, Martín. Livro das confissões, op. cit., v. II, p. 105-106.

${ }^{41}$ Martín Pérez chega a mencionar o Penitencial de Beda como uma de suas fontes. PÉREZ, Martín. Livro das confissöes, op. cit., v. II, p. 216.
} 
da consciência dos fiéis pecadores. ${ }^{42} \mathrm{O}$ modelo de confissão penitencial apresentado por Clemente Sánchez e Martín Pérez começou a ser, desse modo, lapidado e difundido, já no século XII, por grandes pensadores que passaram a condenar antigas práticas penitenciais, julgadas por eles, pouco reabilitativas e instrutivas.

Embora Pedro Abelardo fosse de uma época em que a penitência tarifária ainda era aceita e difundida por muitas igrejas das terras latinas, sua produção escrita ajudou, contudo, a inaugurar, em meados do século XII, uma nova fase da pastoral cristã. ${ }^{43} \mathrm{Na}$ obra Conheça a ti mesmo, esse pensador assevera que, "se a intençấo é reta, toda a soma de obras que dela procedem" é digna de luz, "ou seja, será boa". Se a intenção fosse, porém, maldosa, seus efeitos não poderiam gerar outros frutos que não fossem açóes pecaminosas e perversas. ${ }^{44} \mathrm{~A}$ partir de indicativos como esses, em que a consciência individual é apontada como o motor das virtudes e desvirtudes humanas, esse pensador lançou os alicerces de um princípio jurídico e pedagógico conhecido como "moral da intenção", pelo qual o penitente não poderia ser julgado apenas pelas consequências negativas de suas açôes, mas sobretudo pela intenção de querer ou não praticá-las. ${ }^{45}$ Este é um raciocínio a respeito da avaliação dos impulsos individuais que aparece também na obra Dos sacramentos, de Hugo de S. Victor, pensador contemporâneo a Abelardo, na qual conclamam ao cristão a conhecer melhor a si mesmo, isto é, a aprenderas condutas e os hábitos considerados próprios de seu estado e ofício. ${ }^{46} \mathrm{O}$ "conhece-te a ti mesmo" - embora tenha sido elaborado por Sócrates, na Antiguidade grega, ${ }^{47}$ com o propósito de inspirar as pessoas a refletirem sobre os benefícios morais do exame de seus limites e potencialidades $-{ }^{48}$ foi retomado, portanto, entre os séculos XII e XIII, sob um revestimento cristão, para servir como um tipo de exercício de autoanálise que ajudaria o fiel a descobrir o que deveria ou não fazer no cotidiano. ${ }^{49}$

Devedor dessa corrente inspirada em premissas do pensamento socrático, o autor do Tratado de confissão, ao dissertar sobre o nono mandamento da Igreja (não desejar a mulher do próximo), defendeu, nestas palavras, que existem formas diferentes de cobiça e, por isso

\footnotetext{
${ }^{42}$ RAMOS-REGIDOR, José. Teologia do sacramento da penitência, op. cit., p. 107-108.

${ }^{43}$ PAYEN, Jean-Charles. Le motif du repentir dans la littérature français e médiévale (Des origines à 1230). Genève: LibraireDroz, 1967, p. 59-61.

${ }^{44}$ PEDRO ABELARDO. Conócete a ti mesmo. Estudio y notas de Pedro R. Santidrían. Madri: Editorial Tecnos, 2002, p. 50.

${ }^{45}$ CHENU, Marie-Dominique. O despertar da consciência na civilização medieval. Sáo Paulo: Ediçôes Loyola, 2006, p.20.

${ }^{46}$ GILSON, Étienne. O espirito da filosofia medieval. São Paulo: Martins Fontes, 2006, p. 288-289.

${ }^{47}$ Para uma visão geral do modo como era o ensino no mundo antigo, sugiro: HADOT, Pierre. O que é a filosofia antiga? São Paulo: Loyola, 2014.

${ }^{48}$ FOUCAULT, Michel. A hermenêutica do sujeito. São Paulo: Martins Fontes, 2006, p. 16-17.

${ }^{49}$ CHENU, Marie-Dominique. O despertar da consciência na civilização medieval, op. cit., p. 37-41. Sobre a manutenção da confissão penitencial nas terras latinas, sugiro ainda: PRODI, Paolo. Uma história da justiça. São Paulo: Martins Fontes, 2005.
} 
mesmo, o varão precisaria ser inquirido corretamente para que o confessor encontrasse as causas de seus estímulos luxuriosos:

A cobiça pode ser feita de duas maneiras, pode ser ela um pecado mortal ou venial. Exemplo: vai um homem por uma rua, viu uma mulher e cobiçou-a. Se mais não foi, é pecado venial [...]. Mas aquele que cobiça aquela mulher, se lhe dura aquela cobiça, ou faz alguns autos, assim como demandá-la, ou fazê-la demandar, ou lhe prazeria de a ouvir, ou muda passos ou gestos, ou outras cousas semelhantes, comete pecado mortal. E assim se deve tudo muito bem declarar ao confessor. ${ }^{50}$

A partir do momento em que os confessores são instruídos a observar cada detalhe confesso no interrogatório, vem à tona, pois, a distinção entre pecado venial e pecado mortal. Em um tempo em que "a moral da intenção" abria portas para novas linhas do pensamento jurídico, o pecado mortal começou a ser visto como uma açáo deliberada pela consciência do pecador, enquanto o pecado venial, ao contrário, era considerado fruto de distração ou falta de conhecimento. Acerca dessa cara distinção entre os ramos dos pecados, o já referido bispo de Ceuta, D. Diogo Ortiz, não se distanciou da opinião do autor do Tratado de confissão, ao explicar, de maneira simples e direta, a seguinte diferença entre pecado mortal e venial:

Pecado venial, como abaixo diremos, se diz porque ligeiramente se perdoa e não destrói a vida da alma, que é a graça, e não nos aparta do último fim, que é Deus, posto que nos retarda a chegada no caminho e nos faz tíbios no amor e na caridade [...] Já pecado mortal nos tolhe a graça que é vida da alma e nos aparta do fim derradeiro, que é Deus [... $]^{51}$

Sugere D. Ortiz que os curas deveriam descobrir a causa motora dos erros do penitente, como se a vida, para o confessor de D. João II, fosse um quebra-cabeça e esses clérigos precisassem saber qual peça dava liga às demais. Dado que os pecados veniais não eram considerados erros graves, Guido de Monte Roterio instruiu os confessores, inclusive, a orientar o penitente a qualificar os deslizes de acordo com sua gravidade para que este confessasse apenas os pecados mortais já cometidos. ${ }^{52}$ Não só este clérigo como muitos de seus congêneres coetâneos defendiam que os confessores precisavam ser "professores da lei sagrada", 53 já que a confissão também era, para eles, uma espécie de "escola" cujas aulas serviriam para os fiéis tirarem dúvidas acerca dos dogmas cristãos e conhecerem melhor os tipos de pecados que eram catalogados pelos tratados de confissão.

\footnotetext{
${ }^{50}$ TRATADO de confissão. Ed. José Barbosa Machado. Braga: Edições Vercial, 2010. p. 58.

${ }^{51}$ TRATADO de confissão, op. cit., p. 229-230.

${ }^{52}$ GUIDO DE MONTE ROTERIO. Manipulus Curatorum, f. $111 \mathrm{r}$.

${ }^{53}$ Ibidem, f. 7r.
} 
A principal lição a ser ensinada nessa "escola" era saber, pois, examinar as lembranças relativas aos pecados mortais cometidos no passado. Na medida em que se tornava, portanto, imprescindível a correção das máculas deixadas pelos pecados mortais, os confessores iam aprendendo a extrair dos cristãos seus segredos mais íntimos, aqueles que permitiriam a decifração de cada enigma escondido por trás de seus deslizes. Para autores de tratados de confissão, refletir sobre o passado definia-se, a propósito, como um frutífero mecanismo de meditação, pelo qual o fiel descobriria o modo mais adequado de gerir a própria vida. Foi o que defendeu, por exemplo, Martín Pérez, ao mencionar que o fiel pecador, a partir do momento em que se arrependesse "por seu passado", passaria a desejar, no presente e nos tempos vindouros, apenas açôes saudáveis e prazerosas ao espírito. ${ }^{54}$ Guido de Monte Roterio, por sua vez, asseverou que o pecador deveria confessar enquanto ainda possuísse "memória dos pecados cometidos", ou seja, ninguém poderia ser negligente, segundo ele, a ponto de se esquecer de listar algum erro grave para seu confessor..$^{55}$ No final do século XIII, o fiel começava a ser orientado, portanto - durante sermóes públicos, missas e nos encontros com clérigos - a exercitar sua memória e a vasculhar seu passado para que se lembrasse dos pecados mortais praticados; mais precisamente, era instruído, nesses tempos, a avaliar cada uma de suas experiências de vida para saber classificá-las como benéficas ou maléficas. ${ }^{56}$

Ao estruturar um esquema sobre o modo como as experiências maléficas deveriam ser externadas, Pérez explicou, no Livro das confissöes, que,

[...] na penitência, tem de haver três coisas. A primeira é contrição. A segunda é confissão pela boca. A terceira satisfação pela obra. E estas três coisas juntas fazem a penitência acabada. Convém que o pecador que quer fazer emenda e cumprida penitência dos seus pecados, que bem de coraçáo se arrependa e que os confesse pela boca e faça emenda deles por obras. ${ }^{57}$ (grifos nossos)

Em outra altura desse mesmo tratado, por meio de uma linguagem metafórica, esse mesmo Pérez adita que tal exercício purificador corresponde "a uma jornada pelo deserto da penitência", uma jornada composta por três paradas; na primeira, "a alma é lavada da culpa"; na segunda, ocorre o "descobrimento dos pecados diante do sacerdote"; na terceira, quando os segredos já foram descortinados e os pecados listados, cabe apenas ao penitente emendá-los por meio de jejuns e preces..$^{58}$ Como um viajante que, ao atravessar o deserto, vê seu corpo se debilitando a cada dia, esse clérigo cultivado declarou que o penitente precisava, ao longo dessa "jornada”, mostrar sinais visíveis de dor e sofrimento. Uma sensação

\footnotetext{
${ }^{54}$ PÉREZ, Martín. Livro das confissóes, op. cit., v. II, p. 66.

${ }^{55}$ GUIDO DE MONTE ROTERIO. Manipulus Curatorum, op. cit., f. $104 \mathrm{v}$.

${ }^{56}$ Cf. YATES, Francis. A arte da memória. Campinas: Editora Unicamp, 2007, p. 103-105.

${ }^{57}$ PÉREZ, Martín. Livro das confissöes, op. cit., v. II, p. 93.

${ }^{58}$ Ibidem, p. 70.
} 
externada que, ao contrário, porém, de simbolizar uma derrota ou perda, era considerada a prova máxima da vitória humana sobre a tentação. Na verdade, a metáfora da travessia por um deserto como alusão à correçáo dos pecados servia para naturalizar a ideia de que a purgação dos pecados deveria ser um processo dispendioso, doloroso e exaustivo. A partir de uma escrita que combinava exemplos metafóricos com uma casuística bastante extensa acerca de todos os pecados mortais, não só Pérez como outros autores de tratados de confissão buscaram orientar, desse modo, o confessor para saber executar adequadamente cada etapa do sacramento da Penitência.

Como a confissão penitencial e a pregação pública eram realizadas, na maioria das vezes, em português muitos prelados de Portugal começaram a estimular a tradução de regras e conselhos, sobretudo, do castelhano e do latim para o vernáculo com a finalidade de familiarizar párocos e missionários mendicantes com os termos e as expressóes que precisavam utilizar em suas prédicas. Ao definir o significado e o uso de termos caros ao pensamento cristão como "pecado mortal", "pecado venial", "remissão", "arrependimento" e "penitência”, o Livro das confissöes, de Martín Pérez, o Sacramental, de Clemente Sánchez, e o Tratado de confissão, de um autor anônimo, inventariaram as principais práticas e técnicas relativas à purgaçáo dos pecados mortais, ou melhor, ajudaram a introduzir no vocabulário corrente dos portugueses palavras que precisavam ser memorizadas e naturalizadas pelos fiéis cristáos. Dito de outro modo, clérigos cultivados sugeriam que o universo vocabular dos confessores e leigos poderia ser alargado, portanto, com o uso desse tipo de material pedagógico, mas, dados os limites deste ensaio, um inventário mais completo e detalhado desse quadro de palavras e expressões ficará, pois, para outro trabalho.

Em síntese, a partir do século XII, não foram, a propósito, poucos os clérigos que, interessados em reavaliar as estratégicas pedagógicas da Igreja, passaram a projetar novos usos para a confissão. Se os pensadores cristáos do século XII inovaram por propor o exame da consciência como o meio mais fecundo para a purificação da vida, teólogos posteriores como Clemente Sánchez, Martín Pérez e D. Diogo Ortiz - esforçaram-se para elaborar questôes e prédicas que pudessem facilitar o ofício do confessor na hora de desvendar a consciência do penitente. Mais precisamente, enquanto os primeiros escolásticos projetaram as bases da confissão penitencial, foram os clérigos dos séculos XIV e XV os principais responsáveis por instituí-la em diferentes plagas do mundo cristão, principalmente em lugares distantes dos grandes centros urbanos.

\section{Referências Bibliográficas}

BEZLER, Francis. Les pénitentiels espagnols. Contribution à l'étude de la civilisation de l'Espagnechré tienne du haut Moyen Âge. Münster: Aschendorff Verlag, 1994. 
BRAGANÇA, Joaquim. Liturgia e espiritualidade na Idade Média. Lisboa: Universidade Católica Editora, 2008.

CHENU, Marie-Dominique. O Despertar da consciência na civilização medieval. São Paulo: Ediçôes Loyola, 2006.

CHIFFOLEAU, Jacques. Avouerl'inavouable. L'aveu et la procédure inquisitoire à la findu Moyen Age. In: DULONG, Renaud (Dir.). L'aveu. Histoire, sociologie, philosophie. Paris: Puf, 2001.

DELUMEAU, Jean. A confissão e o perdão. São Paulo: Companhia das Letras, 1991.

DIOGO ORTIZ. O catecismo pequeno. Ed. de Elsa Maria Branco da Silva. Lisboa: Ediçóes Colibri, 2001.

DULONG, Renaud (Dir.). L'aveu. Histoire, sociologie, philosophie. Paris: Puf, 2001.

FOUCAULT, Michel. A hermenêutica do sujeito. São Paulo: Martins Fontes, 2006. . Os anormais. São Paulo: Martins Fontes, 2002.

FRANÇA, Susani Silveira Lemos. Os reinos dos cronistas medievais (Século XV). São Paulo: Annablume, 2006.

GILSON, Étienne. O espirito da filosofia medieval. São Paulo: Martins Fontes, 2006.

GUIDO DE MONTE ROTERIO. Manipulus curatorum. Lisboa: Germano Gallarde, 1523. HADOT, Pierre. O que é a filosofia antiga? São Paulo: Loyola, 2014.

MACEDO, José Rivair. Os manuais de confissão luso-castelhanos dos séculos XIII-XV, Revista Aedos, v. 2, n. 2, 2009.

MICHAUD-QUANTIN, Pierre. Les méthodes de la pastorale duXIII'auXV'siècle. Miscellanea media e valia, v. 7, 1970.

. Sommes de casuistique et manuels de confessionau Moyen Âge (XII-XVI siècles). Louvain: Nauwelaerts, 1962.

MINOIS, Georges. Le confesseur du roi. Les directeurs de consciencesous la monarchie française. Paris: Fayard, 1988.

NIETO SORIA, José Manuel; SANZ SANCHO, Iluminado. La época medieval: Iglesia y cultura. Madri: Ediciones Istmo, 2002.

PAYEN, Jean-Charles. Le motif du repentir dans la littérature française médiévale (Des origines à 1230).Genève: Libraire Droz, 1967.

PEDRO ABELARDO. Conócete a ti mesmo. Estudio y notas de Pedro R. Santidrían. Madri: Editorial Tecnos, 2002.

PÉREZ, Martín. Livro das confissōes. Edição de José Barbosa Machado e Fernando Torres Moreira. Vila Real: Pena Perfeita, 2005-2006, 2 vol.

PRODI, Paolo. Uma história da justiça. São Paulo: Martins Fontes, 2005. 
PROSPERI, Adriano. Tribunais da consciência: inquisidores, confessores, missionários. São Paulo: Edusp, 2013.

RAMOS-REGIDOR, José. Teologia do sacramento da penitência. São Paulo: Paulus, 2006. REINHARDT, Klaus; SANTIAGO-OTERO, Horacio. Biblioteca bíblica ibérica medieval. Madri: Consejo Superior de Investigaciones Científicas, 1986.

RESENDE, Garcia de. Breve memorial dos pecados e cousas que pertenecem ha confissam hordenado. Ed. Joaquim Bragança. Lisboa: [s. n.], 1980.

. Crónica de D. João II e Miscelânea. Ed. Joaquim Serrão. Lisboa: Imprensa Nacional Casa da Moeda, 1973.

ROUCHE, Michel. Histoire de l'enseignementet de l'éducation. Paris: Édition Perrin, 2003.

SAENGER, Paul. La lectura en los últimos siglos de la Edad Media. In: CHARTIER, Roger; CAVALLO, Guglielmo (Org.). Historia de lalectura. Madri: Taurus, 2011.

SÁNCHEZ, Clemente. Sacramental. Edição de José Barbosa Machado. Braga: Edições Vercial, 2010.

SCHMITT, Jean-Claude. La raison des gestes dans l'Occident Médiéval. Paris: Gallimard, 1990.

SERRÃO, Joaquim. Figuras e caminhos do Renascimento em Portugal. Lisboa: Imprensa Nacional Casa da Moeda, 1994.

SOTO RÁBANOS, Jose María. Visión y tratamiento del pecado en los manuales de confesión de la Baja Edad Media hispana, Hispania Sacra, v. LVIII, n. 118, p. 411-447, jul./ dec.2006.

TOMÁS DE AQUINO. Suma teológica. São Paulo: Ediçôes Loyola, 2006, v. IX.

TRATADO de confissão. Ed. José Barbosa Machado. Braga: Ediçóes Vercial, 2010.

VOGEL, Cyrille. Le pécheur et la Pénitenceau Moyen Age. Paris: Cerf, 2007.

YATES, Francis. A arte da memória. Campinas: Editora Unicamp, 2007. 